\title{
Research on The Evaluation Index System and The Grey Clustering Analysis Model of Teaching Quality of Physical Education in Higher Education
}

\author{
http://dx.doi.org/10.3991/ijet.v10i8.5281
}

Baoquan $\mathrm{Wu}$

Henan Vocational and Technical College of Communications, Zhengzhou, Henan, China

\begin{abstract}
Teaching quality evaluation of physical education usually involves multiple influence factors with grey and uncertain information. This brings about limitations to effective evaluation of teaching quality of physical education in colleges and universities. Thus, this paper draws merits from previous research and proposes a teaching quality evaluation system and model of physical education in colleges and universities. First, based on real situations, grey categories of evaluation state for physical education teaching quality are established. The definite weighted functions of grey category of evaluation state are confirmed. Specific steps of the teaching quality evaluation model based on grey clustering analysis are accounted for. Finally, a case study is introduced to verify the model. This model enlightens a new way to evaluate teaching quality of physical education in colleges and universities.
\end{abstract}

Index Terms-Colleges and universities, Evaluation model, Grey clustering analysis, Sports science, Teaching quality.

\section{INTRODUCTION}

Constructing the teaching quality evaluation system and model of physical education holds much significance. On one hand, teaching quality of physical education can be measured so as to enhance their teaching quality and ability. On the other hand, colleges and universities can rely on the feedback from the evaluation to conduct effective management and improve the teaching quality on the whole ${ }^{[1-3]}$. At the present time, many experts and scholars have taken interest in relevant research and studied how to improve the teaching quality of physical education. They have yielded fruitful results ${ }^{[4-8]}$. However, there usually falls short of information about the teaching quality of physical education for evaluation. Sometimes, the information acquired is fuzzy and uncertain, which limits the evaluation to some extent. Consequently, this paper proposes an improved evaluation index system. On the basis of grey system theory, small samples that fall short of information can be addressed $\left.{ }^{[9-12}\right]$. The grey clustering analysis model established in this paper can enlighten a new way of evaluating teaching quality of physical education in higher education and holds significance to improve the teaching quality of physical education.

\section{TEaching Quality Evaluation SYSTEM OF} PHYSICAL EDUCATION IN COLLEGES AND UNIVERSITIES

The selection of indicators should follow basic principles as listed below:
(1) Principle of scientificity: indicators should not violate the truth of science. They should be rational and have compliance with clear definitions.

(2) Principle of objectivity: the selection of indicators should be based on objectivity rather than subjectivity and indicators should reflect real situation in an objective and accurate way.

(3) Principle of comprehensiveness: indicators should cover all important features of teaching quality in order to analyze it in a complete way.

(4) Principle of representativeness: not all influence factors of teaching quality should be considered. Indicators selected should represent important features of teaching quality.

(5) Principle of operability: indicators should be able to measured and transformed. Therefore, only operable indicators can be selected.

Based on abovementioned principles, this paper evaluate the teaching quality of physical education in colleges and universities from five perspectives, namely teaching content, teaching method, teaching effect and teaching planning. The evaluation index system is shown in Table 1.

TABLE I.

TEACHING QUALITY EVALUATION SYSTEM OF PHYSICAL EDUCATION IN COLLEGES AND UNIVERSITIES

\begin{tabular}{|c|c|c|}
\hline System layer & $\begin{array}{l}\text { First class indi- } \\
\text { cator }\end{array}$ & Second class indicator \\
\hline \multirow{8}{*}{$\begin{array}{l}\text { Teaching quality } \\
\text { evaluation sys- } \\
\text { tem of physical } \\
\text { education in } \\
\text { colleges and } \\
\text { universities } \\
U\end{array}$} & \multirow{3}{*}{$\begin{array}{c}\text { Teaching capaci- } \\
\text { ty } U_{1}\end{array}$} & professional capacity $u_{11}$ \\
\hline & & $\begin{array}{l}\text { research and innovative } \\
\text { capacity } \mathcal{u}_{12}\end{array}$ \\
\hline & & integration capacity $u_{13}$ \\
\hline & \multirow{3}{*}{$\begin{array}{c}\text { Teaching content } \\
U_{2}\end{array}$} & $\begin{array}{l}\text { clarity of teaching goal } \\
\qquad u_{21}\end{array}$ \\
\hline & & $\begin{array}{l}\text { scientific nature of teach- } \\
\text { ing content } u_{22}\end{array}$ \\
\hline & & $\begin{array}{c}\text { adequacy of teaching } \\
\text { content } u_{23}\end{array}$ \\
\hline & \multirow{2}{*}{$\begin{array}{c}\text { Teaching method } \\
U_{3}\end{array}$} & $\begin{array}{c}\text { guidance of teaching } \\
\text { method } u_{31}\end{array}$ \\
\hline & & scientific nature of teach- \\
\hline
\end{tabular}



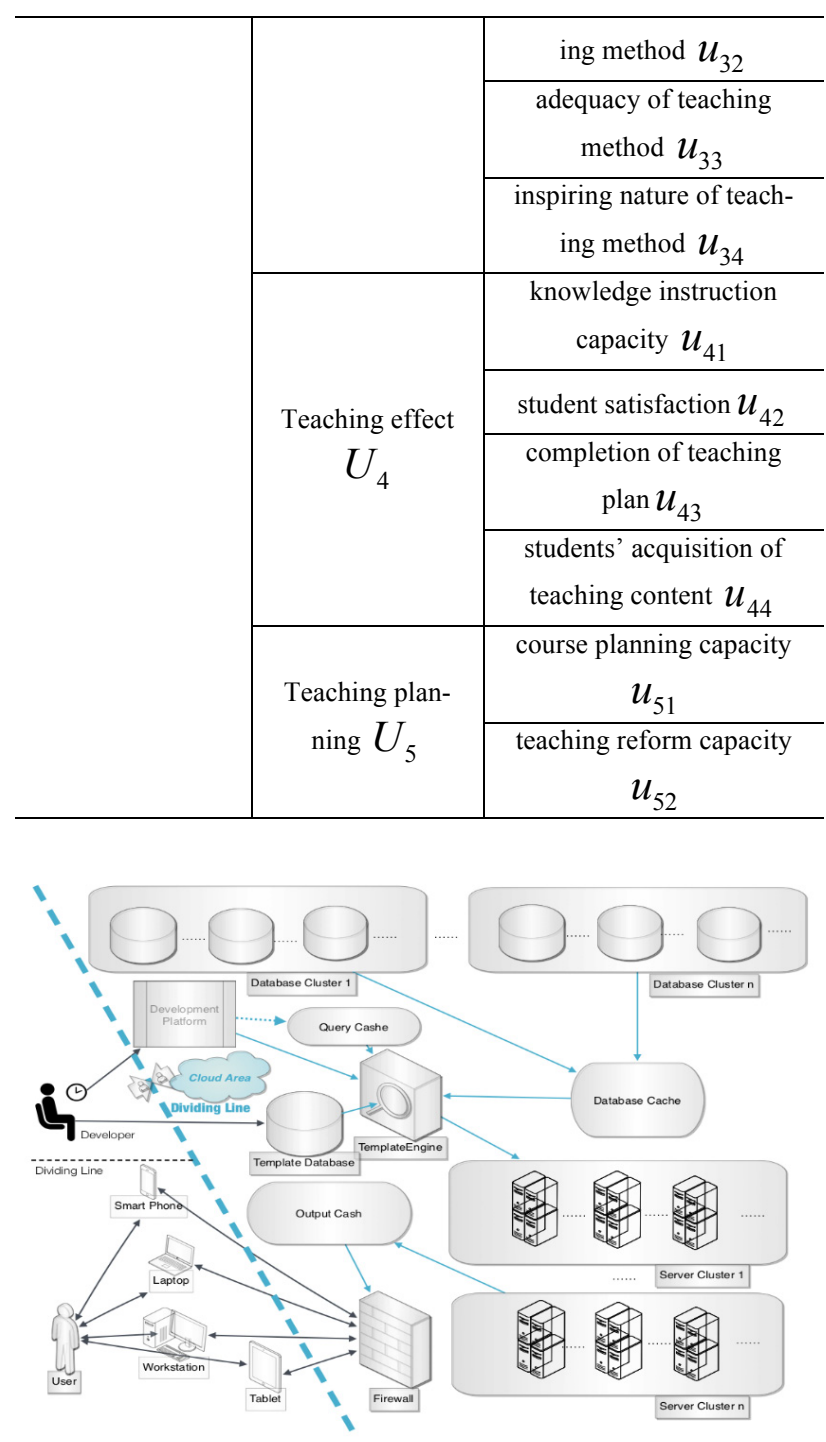

Figure 1. Cloud Services Architecture.

III. Grey Clustering ANALysis Model of TEACHING QUALITY OF PHYSICAL EDUCATION IN COLLEGES AND UNIVERSITIES

\section{A. Principles of grey clustering analysis}

Grey clustering analysis refers to that the object under evaluation is analyzed according to multiple clustering indicators to determine which category the object belongs to. Suppose the value of object $i$ about indicator $j$ is $x_{i j}$ and there are ${ }^{S}$ grey categories of indicator $j$, so the k-th definite weighed function is $f_{j}^{k}\left(x_{i j}\right)$, and the grey clustering coefficient $\rho_{i}^{k}$ of k-th category of indicator of $j$ object under evaluation $i$ is:

Where $m$ refers to the number of clustering indicators.

If the weight $w_{j}$ of clustering indicator $j$ is considered, then the grey clustering coefficient $\rho_{i}^{k}$ of the k-th category of indicator of $j$ object under evaluation $i$ is: if it satisfies:

It indicates object $i$ under evaluation belongs to the tth category.

\section{B. Grey category of indicators of teaching quality of physical education in colleges and universities}

Experts are invited to score the teaching quality of physical education according to real situation of physical education in colleges and universities. Teaching quality is divided into five grey categories, namely excellent, qualified, good, mediocre and unqualified. Table II shows the score from experts and the grey category.

TABLE II.

GREY CATEGORY OF TEACHING QUALITY OF PHYSICAL EDUCATION IN COLLEGES AND UNIVERSITIES

\begin{tabular}{c|c|c|c|c|c}
\hline $\begin{array}{c}\text { Grey } \\
\text { category }\end{array}$ & Excellent & Qualified & Good & Mediocre & Unqualified \\
\hline $\begin{array}{c}\text { Category } \\
\text { symbol }\end{array}$ & $\mathrm{H}$ & $\mathrm{L}$ & $\mathrm{Z}$ & $\mathrm{G}$ & $\mathrm{C}$ \\
\hline Score & $90-100$ & $80-90$ & $\begin{array}{c}65- \\
80\end{array}$ & $50-65$ & $0-50$ \\
\hline
\end{tabular}

\section{The construction of definite weighed function}

According to Table II and based on triangle function, semi trapezoidal function and trapezoidal function, the definite weighed functions of five categories can be defined as the followings:

The definite weighed function for "excellent" is: The definite weighed function for "qualified" is: The definite weighed function for "good" is:

The definite weighed function for "mediocre" is:

The definite weighed function for "unqualified" is:

\section{Weight of indicators of teaching quality of physical} education in colleges and universities

In general, the importance of indicators to the evaluation of teaching quality varies from each other. Thus, in the grey clustering analysis, indicators should be allocated with proper weight. There are many methods to determine weight of an indicator. In this paper, AHP is adopted to obtain the weight of indicators.

Firstly, $n$ experts in relevant field are invited to score the indicators. The judgment matrix $\boldsymbol{A}$ of relative importance of indicators is confirmed:

The maximum eigenvalue $\lambda_{\max }(\boldsymbol{A})$ of judgment matrix $\boldsymbol{A}$ and the consistency indicator $C I$ are obtained:

The random indicator $R I$ is obtained by referring to the table and the consistency ratio $C R$ is computed:

If the indicator passes the consistency test, then the weight $w_{i}$ of indicator $i$ is:

\section{E. Grey clustering analysis model and the algorithm}

Suppose the value of indicator $j$ of object under evaluation $i$ is $v_{i j}$, so the grey clustering coefficient $\rho_{i j}^{k}$ of kth grey category of indicator $j$ is obtained according to the definite weighed function $f_{j}^{k}\left(v_{i j}\right)$. Thus, the grey clustering coefficient matrix $\boldsymbol{B}_{i}$ is: 
Consider weight of indicators, the grey clustering coefficient sequence $\boldsymbol{\rho}_{i}^{k}$ of k-th grey category of indicator $j$ is:

If it satisfies:

It indicates object $i$ belongs to the t-th category.

As abovementioned, the grey clustering analysis model has the following steps:

(1) The evaluation index system of teaching quality of physical education is constructed on the basis of real situation in colleges and universities.

(2) Different grey categories of the indicator in the index system are confirmed and the definite weighed functions of grey category are determined. ed.

(3) Weight to indicators on the basis of AHP is allocat-

(4) According to the definite weighed function of grey category, the grey clustering coefficient of the object under evaluation about indicators of different grey categories is obtained.

(5) Which category the object belongs to according to the grey clustering coefficient is confirmed.

\section{CAse Study}

This paper takes the teaching performance of physical teachers in a university as the example to test the teaching quality evaluation system and the grey clustering analysis model. Experts from universities and colleges are invited to score on the object under evaluation. Weight of indicators is allocated on the basis of the score, as shown in Table III.

TABLE III.

WEIGHT OF INDICATORS AND THE SCORES

\begin{tabular}{|c|c|c|c|c|}
\hline $\begin{array}{l}\text { first class } \\
\text { indicator }\end{array}$ & weight & $\begin{array}{l}\text { second class indica- } \\
\text { tor }\end{array}$ & weight & score \\
\hline \multirow{3}{*}{$\begin{array}{c}\text { teaching } \\
\text { capacity } \\
U_{1}\end{array}$} & \multirow{3}{*}{0.241} & $\begin{array}{c}\text { professional capacity } \\
u_{11}\end{array}$ & 0.450 & 86 \\
\hline & & $\begin{array}{l}\text { research and innova- } \\
\text { tive capacity } \mathcal{u}_{12}\end{array}$ & 0.300 & 75 \\
\hline & & $\begin{array}{c}\text { integration capacity } \\
u_{13}\end{array}$ & 0.250 & 72 \\
\hline \multirow{3}{*}{$\begin{array}{l}\text { teaching } \\
\text { content } \\
U_{2}\end{array}$} & \multirow{3}{*}{0.191} & $\begin{array}{l}\text { clarity of teaching } \\
\text { goal } u_{21}\end{array}$ & 0.333 & 92 \\
\hline & & $\begin{array}{c}\text { scientific nature of } \\
\text { teaching content } \\
u_{22}\end{array}$ & 0.333 & 80 \\
\hline & & $\begin{array}{c}\text { adequacy of teaching } \\
\text { content } u_{23}\end{array}$ & 0.333 & 65 \\
\hline \multirow{4}{*}{$\begin{array}{l}\text { teaching } \\
\text { method } \\
U_{3}\end{array}$} & \multirow{4}{*}{0.166} & $\begin{array}{c}\text { guidance of teaching } \\
\text { method } u_{31}\end{array}$ & 0.250 & 78 \\
\hline & & $\begin{array}{c}\text { scientific nature of } \\
\text { teaching method } \\
u_{32}\end{array}$ & 0.250 & 80 \\
\hline & & $\begin{array}{c}\text { adequacy of teaching } \\
\text { method } u_{33}\end{array}$ & 0.250 & 55 \\
\hline & & $\begin{array}{l}\text { inspiring nature of } \\
\text { teaching method }\end{array}$ & 0.250 & 75 \\
\hline
\end{tabular}

\begin{tabular}{c|c|c|c|c}
\hline & & $u_{34}$ & & \\
\hline \multirow{2}{*}{$\begin{array}{c}\text { teaching } \\
\text { effect } U_{4}\end{array}$} & \multirow{2}{*}{0.337} & $\begin{array}{c}\text { knowledge instruc- } \\
\text { tion capacity } u_{41}\end{array}$ & 0.250 & 83 \\
\cline { 3 - 5 } & & $\begin{array}{c}\boldsymbol{u}_{42} \\
\text { student satisfaction }\end{array}$ & 0.200 & 85 \\
\cline { 3 - 5 } & & $\begin{array}{c}\text { completion of teach- } \\
\text { ing plan } u_{43}\end{array}$ & 0.200 & 95 \\
\cline { 3 - 5 } & & $\begin{array}{c}\boldsymbol{u}_{44} \\
\text { of teaching content }\end{array}$ & 0.350 & 75 \\
\hline \multirow{2}{*}{$\begin{array}{c}\text { teaching } \\
\text { planning } \\
U_{5}\end{array}$} & \multirow{2}{*}{0.065} & $\begin{array}{c}\text { course planning } \\
\text { capacity } u_{51}\end{array}$ & 0.667 & 88 \\
\cline { 3 - 5 } & $\begin{array}{c}\text { teaching reform } \\
\text { capacity } u_{52}\end{array}$ & 0.333 & 67 \\
\hline
\end{tabular}

By constructing the definite weighted function of grey category, the grey clustering coefficient of object under evaluation can be obtained, as shown in Table IV and V.

TABLE IV.

GREY CLUSTERING COEFFICIENT OF SECOND CLASS INDICATORS

\begin{tabular}{|c|c|c|c|c|c|}
\hline \multirow{2}{*}{ second class indicator } & \multicolumn{5}{|c|}{ grey category } \\
\hline & $\mathrm{H}$ & $\mathrm{L}$ & $\mathrm{Z}$ & $\mathrm{G}$ & $\mathrm{C}$ \\
\hline $\begin{array}{l}\text { professional capacity } \\
u_{11}\end{array}$ & 0 & 0.8 & 0 & 0 & 0 \\
\hline $\begin{array}{c}\text { research and innovative } \\
\text { capacity } u_{12}\end{array}$ & 0 & 0 & 1.0 & 0 & 0 \\
\hline $\begin{array}{c}\text { integration capacity } \\
u_{13}\end{array}$ & 0 & 0 & 1.0 & 0 & 0 \\
\hline $\begin{array}{l}\text { clarity of teaching goal } \\
\qquad u_{21}\end{array}$ & 0.4 & 0 & 0 & 0 & 0 \\
\hline $\begin{array}{c}\text { scientific nature of } \\
\text { teaching content } u_{22}\end{array}$ & 0 & 1.0 & 0 & 0 & 0 \\
\hline $\begin{array}{c}\text { adequacy of teaching } \\
\text { content } u_{23}\end{array}$ & 0 & 0 & 0 & 1.0 & 0 \\
\hline $\begin{array}{c}\text { guidance of teaching } \\
\text { method } u_{31}\end{array}$ & 0 & 0 & 0.4 & 0 & 0 \\
\hline $\begin{array}{c}\text { scientific nature of } \\
\text { teaching method } u_{32}\end{array}$ & 0 & 0 & 1.0 & 0 & 0 \\
\hline $\begin{array}{c}\text { adequacy of teaching } \\
\text { method } u_{33}\end{array}$ & 0 & 0 & 0 & 1.0 & 0 \\
\hline $\begin{array}{c}\text { inspiring nature of } \\
\text { teaching method } u_{34}\end{array}$ & 0 & 0 & 1.0 & 0 & 0 \\
\hline $\begin{array}{c}\text { knowledge instruction } \\
\text { capacity } u_{41}\end{array}$ & 0 & 0.6 & 0 & 0 & 0 \\
\hline $\begin{array}{l}\text { student satisfaction } \\
u_{42}\end{array}$ & 0 & 1.0 & 0 & 0 & 0 \\
\hline $\begin{array}{l}\text { completion of teaching } \\
\text { plan } u_{43}\end{array}$ & 1.0 & 0 & 0 & 0 & 0 \\
\hline $\begin{array}{l}\text { students' acquisition of } \\
\text { teaching content } u_{44}\end{array}$ & 0 & 0 & 1.0 & 0 & 0 \\
\hline course planning capaci- & 0 & 0.8 & 0 & 0 & 0 \\
\hline
\end{tabular}




\begin{tabular}{c|c|c|c|c|c}
\hline ty $u_{51}$ & & & & & \\
\hline $\begin{array}{c}\text { teaching reform capaci- } \\
\text { ty } \boldsymbol{u}_{52}\end{array}$ & 0 & 0 & 0.4 & 0 & 0 \\
\hline
\end{tabular}

TABLE V.

GREY CLUSTERING COEFFICIENT OF FIRST CLASS INDICATORS

\begin{tabular}{c|c|c|c|c|c}
\hline first class indica- & \multicolumn{5}{|c}{ grey category } \\
\cline { 2 - 6 } tor & $\mathrm{H}$ & $\mathrm{L}$ & $\mathrm{Z}$ & $\mathrm{G}$ & $\mathrm{C}$ \\
\hline $\begin{array}{c}\text { teaching capacity } \\
U_{1}\end{array}$ & 0 & 0.36 & 0.55 & 0 & 0 \\
\hline $\begin{array}{c}\text { teaching content } \\
U_{2}\end{array}$ & 0.133 & 0.333 & 0 & 0.333 & 0 \\
\hline $\begin{array}{c}\text { teaching method } \\
U_{3}\end{array}$ & 0 & 0 & 0.60 & 0.25 & 0 \\
\hline $\begin{array}{c}\text { teaching effect } \\
U_{4}\end{array}$ & 0.20 & 0.35 & 0.35 & 0 & 0 \\
\hline $\begin{array}{c}\text { teaching plan- } \\
\text { ning } U_{5}\end{array}$ & 0 & 0.534 & 0.133 & 0 & 0 \\
\hline
\end{tabular}

Consequently, the comprehensive weighed grey clustering coefficient for grey categories of the object under evaluation can be obtained, as shown in Table VI. From Table VI, it is seen that the teaching quality of the object under evaluation belongs to category $\mathrm{Z}$ and is closer to category $L$ than to $G$. So the teaching quality of the object under evaluation is at the "good" level but close to "qualified".

TABLE VI.

COMPREHENSIVE COEFFICIENT OF GREY CLUSTERING ANALYSIS OF OBJECT UNDER EVALUATION

\begin{tabular}{c|c|c|c|c|c}
\hline \multirow{2}{*}{$\begin{array}{c}\text { object under } \\
\text { evaluation }\end{array}$} & \multicolumn{5}{|c}{ grey category } \\
\cline { 2 - 6 } & $\mathrm{H}$ & $\mathrm{L}$ & $\mathrm{Z}$ & $\mathrm{G}$ & $\mathrm{C}$ \\
\hline $\begin{array}{c}\text { comprehensive } \\
\text { coefficient of } \\
\text { grey clustering } \\
\text { analysis }\end{array}$ & 0.0928 & 0.3030 & 0.3587 & 0.1051 & 0 \\
\hline
\end{tabular}

\section{CONCLUSIONS}

This paper studies the evaluation of teaching quality of physical education in colleges and universities and proposes an evaluation index system and the grey clustering analysis model. On the basis of grey system theory, grey categories of evaluation state are established and definite weighted functions are confirmed to obtain grey clustering coefficient. The category of the object under evaluation is determined according to the grey clustering coefficient. The case study proves the efficacy of the evaluation index system and the evaluation model, both of which serve as a new method for intelligent evaluation of physical education quality.

\section{REFERENCES}

[1] Yan Yufeng. The Construction of Evaluation Index System of College Sports Culture in China [J] Bulletin of Sport Science \& Technology, 2012, 20(7): 103-105.

[2] Wang Jianmin. Evaluation on Teaching Quality of Technical Class for Physical Education Major [J]. Bulletin of Sport Science \& Technology, 2008, 16(10): 13-14.

[3] Zheng Danheng. Study on Methods Evaluating Class Teaching of PE in Colleges [J]. JOURNAL OF GUANGZHOU PHYSICAL EDUCATION INSTITUTE.2005, 25(1): 117-120.

[4] Ding Hongna. Construction on Teaching Quality Evaluation Index System of College Physical Education Teach [J]. Bulletin of Sport Science \& Technology, 2009, 17(10): 122 -123.

[5] Gao Shen. Research on the Method for Evaluating PE Course in Common Colleges [J]. JOURNAL OF TIANJIN INSTITUTE OF PHYSICAL EDUCATION, 2004, 19 (3): 90-92.

[6] Liu Zhiqun. The Applicative Research of AHP in Sport Teaching's Quality Evaluation [J] JOURNAL OF LANGFANG TEACHERS COLLEGE, 2010, 10(6): 134-136.

[7] Fang Qiang. Study on the AHP of Evaluation System of PE Teaching Quality in Universities [J]. Journal of Guangzhou Sport University.2010, 30(3): 109-112.

[8] He Jieming. Application of Fuzzy Matter Element Clustering Method in Evaluation of Sports Classroom Teaching Ability [J]. Sports Sciences Researches, 2012, 16(1): 72-75.

\section{AUTHOR}

Wu Baoquan. <1965.3>, <Zhengzhou, Henan, P.R.China>. Current position: the associate professor of college of physical education, Henan Vocational and Technical College of Communications, Zhengzhou, Henan, 450000, China. Scientific interest: His research interest fields include the function of sports and physical education. Publications: more than 10 papers published Experience: He has 25 years of Education experience, has completed two scientific research projects. E-mail: wbq_315@163.com.

Submitted 07 November 2015. Published as resubmitted by the author 05 December 2015. 